\title{
Boosting Indonesia's Tourism Sector to be Competitive
}

\author{
${ }^{1}$ Ahmad Zafrullah Tayibnapis, 2Made Siti Sundari \\ 1,2Surabaya University, Indonesia
}

\begin{abstract}
At present and in the future Indonesia still relies heavily on tourism to cover the current account deficit and the state budget deficit. In fact, every year it is quite difficult to reach the target of tourists to visit Indonesia because of various obstacles that should be overcome by the government and tourism business actors. Therefore, this research aims to boost tourism sector through increasing competitiveness. This research analysis refers to the views of Crouch \& Ritchie (OECD, 1999). This qualitative research uses secondary data and primary data that are processed and analyzed comprehensively. The findings of this research prove that the government has done a lot for the development of tourism and set 10 main destinations as tourism icons. On the other hand, there are still disharmony and sectoral ego between the ministry and the local government so as to reduce competitiveness, such as lack of promotional activities, the high price of domestic flight tickets, and limited number of tourism ports.
\end{abstract}

\section{Keywords}

Competitiveness, Attractive Destination, Promotion, Tourism.

\section{Introduction}

Indonesia's tourism sector continues to be encouraged to become one of the major foreign exchange earner sectors and has a direct impact on the people involved in tourism activities in the hope of covering current account deficits, increasing employment, and moving Micro, Small and Medium Enterprises (MSMEs). It should be understood that the tourism sector has direct and indirect impacts on the domestic economy. Indirectly the development of the tourism sector is able to absorb labor so that it has an impact on increasing economic growth. In addition, the tourism sector can directly increase capital flows to Indonesia.

Indonesia has many attractive tourist destinations, such as Borobudur Temple, Mount Bromo, Lake Toba, Raja Ampat, Labuan Bajo, and others. The government of Indonesia tries to increase the number of overseas visitors through the exemption of visitor visas for 169 countries, accelerate the development of transportation infrastructure so that tourist destinations are accessible, and echo the image of Indonesian tourism Wonderful Indonesia. However, the target number of visitors tends to be difficult to achieve due to various factors, such as volcanic eruptions, tsunami disasters, and others.

The contribution of tourism to the Gross Domestic Product (GDP) and foreign exchange supply for Indonesia is still lagging behind Singapore, Thailand and Malaysia due to the low competitiveness index, especially relating to the availability of information and communication technology, tourism service infrastructure, and health and hygiene issues. Other problems that also reduce competitiveness are institutional factors (especially in regions), security factors (prone to crime and dishonesty in transactions), and low awareness. Indonesia's desire to become a shopping paradise, as one part of the tourism industry, seems to be still difficult to realize due to the lack of support, for example the tax refund process that is still difficult for tourists, the small number of shops incorporated in tax returns, and the absence of factory outlets.

Other problems that also hamper the development of tourism in Indonesia are the lack of promotional activities to attract tourists and the lack of focus on the development of tourist destinations which results in the non-optimal achievement of the tourism sector. In addition, access to tourist destinations is often constrained by the price of domestic flight tickets which is more expensive than the price of international flight tickets. This makes tourists think twice about visiting other tourist destinations that must be reached by airplane, and finally the length of stay in Indonesia is not optimal.

\section{Literature Review}

Tourism competitiveness in Indonesia can be approached by the views of Crouch \& Ritchie (1999) adapted from Michael Porter's model, in which the attractiveness of tourist destinations is influenced by 4 components: (1) core resources \& attractors; (2) supporting factors \&resources; (3) destination management; and (4) qualifying determination (OECD, 1999).

Table 1: Destination Attractiveness

\begin{tabular}{|c|c|c|c|c|}
\hline \multicolumn{5}{|c|}{ Destination Attractiveness } \\
\hline Component & $\begin{array}{l}\text { Core Resources \& } \\
\text { Attractors }\end{array}$ & $\begin{array}{l}\text { Supporting Factors \& } \\
\text { Resources }\end{array}$ & Destination Management & Qualifying Determinants \\
\hline Aspect & $\begin{array}{l}\text { 1. Physiography } \\
\text { 2. Culture and History } \\
\text { 3. Market Ties } \\
\text { 4. Mix of Activities } \\
\text { 5. Special Events } \\
\text { 6. Entertainment } \\
\text { 7. Superstructure }\end{array}$ & $\begin{array}{l}\text { 1. Infrastructure } \\
\text { 2. Accessibility } \\
\text { 3. Facilitating Resources } \\
\text { 4. Hospitality } \\
\text { 5. Enterprise }\end{array}$ & $\begin{array}{l}\text { 1. Resources Stewardship } \\
\text { 2. Marketing } \\
\text { 3. Finance \& Venture Capital } \\
\text { 4. Organization } \\
\text { 5. Human Resource } \\
\text { Development } \\
\text { 6. Information / research } \\
\text { 7. Quality of Service } \\
\text { 8. Visitor Management }\end{array}$ & $\begin{array}{l}\text { 1. Location } \\
\text { 2. Interdependencies } \\
\text { 3. Safety/Security } \\
\text { 4. Awareness/Image/Brand } \\
\text { 5. Cost/value }\end{array}$ \\
\hline
\end{tabular}

Source: OECD, The impact of culture in tourism, 2009 
Core resources\& attractors, with 7 aspects, are one of the key factors for potential tourists to determine tourist destinations by always paying attention to the natural state, local culture, event agenda, entertainment, and recreation. Supporting factors and resources, with 5 aspects, are supporters from the trip to the visit to tourist attractions, such as infrastructure, transportation, accommodation services, energy, and others. Destination management, with 8 aspects, is intended to strengthen the quality and effectiveness relating to the obstacles or opportunities faced at each tourist sites. Furthermore, qualifying determinants, with 5 aspects, are very influential on competitiveness that is outside the control of the tourism sector in doing anything.

This research only focuses on 4 aspects: mix of activities, facilitating resources, organization, and location because of the limitations faced by researchers.

\section{Research Method}

This qualitative research focuses on the results of interviews and observations on tourist destinations that are made as the research samples, such as Borobudur Temple, Mount Ijen, Labuan Bajo NTT, shopping tourism in Surabaya, and two tourist villages in Yogyakarta, to see reality, study phenomena, and interpret findings in the field. This study uses secondary data from the Ministry of Tourism and Creative Economy / Tourism and Creative Economy Agency of the Republic of Indonesia, Statistics Indonesia, and the Regency / City Government Tourism Office. Furthermore, primary data was extracted from 50 domestic tourists and 50 overseas tourists in each tourist destination with data triangulation patterns and attempted to capture, record, interpret, and present various information by always holding to the data collection to produce in-depth and comprehensive analysis, including understanding related to the problem in each tourist destination.

This study also seeks to understand the meaning that arises from existing social interactions and the essence of the experience of tourists as a sample by grouping various existing issues and giving meaning to these issues with the support of literature review, such as books, journals, and newspaper articles in daily Kompas. This study is not "free of value", meaning that tourism activities are highly dependent on local values, meanings, culture, and wisdom, given that tourist destination attractiveness is a socially-formed reality through the interaction of business entities and their environment.

\section{Research Findings}

Naturally Indonesia has a large potential of natural and cultural resources to improve tourism, but the weakness lies in the quality of guides, tourism information, destination development, cleanliness, and inadequate tourism service infrastructure. The positive shift in ranking in 2017 and 2019 is due to the reduction in travel constraints and reduced travel costs, as well as the emergence of new tourist attractions and international events, such as sports tourism, fashion, music, and cultural shows.

Indonesia's tourism sector actually has several advantages, one of which is the price is more competitive than in Singapore, Malaysia, and Thailand. But the main problem lies in the limited budget for promotion so competitive prices and attractive packages are not communicated to foreign tourists well. One of the examples is the "Pesona Indonesia" program. Actually there were many tourists who knew the program but they were not encouraged to come because there was no intensive promotion abroad so the achievement of tourism indicators was not optimal, in which the number of international visitors was only $12,948,000$ people with total revenues of approximately 12,530.8 million US dollars or an average revenue per visit of 967.8 US dollars in 2019 only.

Data from the Statistics Indonesia shows that the average length of stay of foreign and domestic guests at star classification hotels reached 1.8 days during July 2019 and increased compared to the average length of stay in July 2018 which was 1.73 days. While the occupancy rate of star hotel rooms in July 2019 averaged $56.73 \%$ or down compared to the average in July 2018 which reached $59.30 \%$.

At present and in the future the tourism sector is truly relied upon to reduce the current account deficit. The tourism sector was targeted to contribute 17.6 billion US dollars of foreign exchange with the arrival of 18 million foreign tourists in 2019. But the realization until September 1, 2019 only reached 9.31 million foreign tourists, even though Indonesia's tourism competitiveness improved two ranks to 40th out of 140 countries in 2019 with a score of 4.3.

The assessment score of 4.3 is based on environmental aspects, travel and tourism conditions, infrastructure, as well as natural and cultural resources. Indonesia's best value in competitiveness is in terms of price, and the lowest value is in environmental sustainability. Singapore is a country in the ASEAN region with the highest ranking, or 17 with a score of 4.8. Malaysia has a score of 4.5 with a ranking of 29 , and Thailand has a score of 4.5 with a ranking of 31 .

Table 2: Tourism Competitiveness Ranking in ASEAN, 2019

\begin{tabular}{|l|l|l|l|}
\hline Country & Score & Ranking 2017 & Ranking 2019 \\
\hline Singapore & 4,8 & 13 & \\
Malaysia & 4,5 & 25 & 17 \\
Thailand & 4,5 & 34 & 29 \\
Indonesia & 4,3 & 42 & 31 \\
Vietnam & 3,9 & 67 & 40 \\
Brunei Darussalam & 3,8 & 74 & 63 \\
The Philippines & 3,8 & 80 & 72 \\
Laos & 3,4 & 94 & 75 \\
Cambodia & 3,4 & 101 & 97 \\
& & & 98 \\
\hline
\end{tabular}

Source: World Economic Forum, 2019

Indonesia's diversity, which includes more than 17 thousand islands, more than 300 ethnic groups, more than 700 languages, world heritage sites, and the third largest biodiversity, is a great potential for tourism development. In the framework of realizing Indonesia as a leading tourism destination, 6 programs have been launched: (1) developing leading destinations; (2) increasing competitiveness; (3) increasing tourism diversity; (4) increasing tourism integration; (5) strengthening as an Asian leading destination; and (6) strengthening as a world leading destination.

The target of 21.6 million overseas visitors by 2020 and 31.8 million by 2025 is realized by setting five super priority destinations, including Lake Toba in North Sumatra Province, Borobudur in Central Java Province, Labuan Bajo in East Nusa Tenggara Province, Mandalika in West Nusa Tenggara Province, and Likupang in North Sulawesi Province. The five tourist destinations 
are part of the 10 priority tourist destinations whose development has been accelerated in the last five years.

Table 3: Target of Overseas Visitors

\begin{tabular}{|l|l|}
\hline Year & Number (x people) \\
\hline 2020 & 21.6 million \\
2025 & 31.8 million \\
2030 & 42.8 million \\
2035 & 57.5 million \\
2040 & 65.1 million \\
2045 & 73.6 million \\
\hline
\end{tabular}

Source: BAPPENAS, 2019

The budget provided to realize the five priority destinations is IDR 9.34 trillion in 2020 to build infrastructure, such as roads, bridges, dams, hotels, commercial areas, airports, and ports. Some priority tourist destinations have also been designated as Special Economic Zones in an effort to attract foreign investors, such as Likupang and Labuan Bajo.

Indonesia is actually very rich in natural tourism and can be an attraction for tourists to come, but it does not necessarily make visiting time longer because natural beauty has not been followed by service offerings from the creative industry sub-sectors, such as fine arts, crafts, and culinary. The creativity that drives the tourism sector has been a real evident in Banyuwangi Regency, such as organizing 99 festivals to attract tourists and make tourists stay longer in Banyuwangi with a target of 2.8 days. On average foreign tourists spent IDR 2.7 million per day per person and domestic tourists spent IDR 1.5 million per day per person in 2018 .

The phenomenon of blue fire in the Crater of Mount Ijen until now is still the mainstay of tourism in Banyuwangi Regency. The Taman Suruh Village Agro-tourism Park at the foot of Mount Ijen covering an area of 8 hectares is used for the Agro Expo Festival capable of attracting 1,000 tourists a day. The Kemiren traditional village, which is one of the villages located on the path that tourists travel to or leave Mount Ijen, always presents cultural and traditional culinary tourism. The number of domestic and foreign visitors in the last eight years shows that tourism and the creative industry have proven to be able to become one of the economic drivers in Banyuwangi Regency, East Java Province.

Nationally, the existence of tourism and the creative industry has been undeniable, given the behavior of the community in travelling has changed and shows something more unique and brave and is not reluctant to spend more when they want to realize dream tourism. The current consumption of society has shifted from ownership of goods to travel and adventure consumption that has been experienced. This means that the leisure segment continues to grow in line with changes in people's lifestyles that make holidays a necessity.

People's consumption patterns have shifted along with digital convenience. The fields of airline ticket services, hotels, and travel ownership experience an increase in transactions due to online sales. In addition, the testimonies of tourists uploaded to several social media have proven to be an effective means of tourism promotion in the current era so that a tourist destination can be more widely known. In applying storynomics tourism, it takes the involvement of communities or tourists who can share their experiences while enjoying a tourist destination, including involving public figures who are considered influential to give testimonials on a tourist destination.

Sports tourism, such as ASIAN Games 2018, ASIAN Para Games 2018, ASEAN Football Federation (AFF) 2018, Tour de Singkarak, Tour de Banyuwangi-Ijen, Tour de Bintan, Tour de Jakarta, Tour de Flores, Bali Run, Borobudur Run, and others, has proven to be effective in boosting the tourism industry. In addition, the activities of the IMF and World Bank meetings in 2018 in Bali also greatly enlivened tourism and the creative industries.

The development of community-based tourism in rural areas has also been proven to be able to sustain the village economy, such as increasing income, reducing unemployment, and suppressing urbanization. For example, a number of villages in the Special Region of Yogyakarta have developed tourism, including Pentingsari Hamlet, Umbulharjo Village, Cangkringan District, Sleman Regency, and Bejiharjo Village, Karangmojo District, Gunung Kidul Regency. Pentingsari Hamlet has developed the concept of village authenticity tourism, and Bejiharjo Village has Pindul Cave tourism. At a minimum the villagers are able to obtain additional income between IDR 1 million to IDR 2 million per month, among others comes from in-house services, village culinary specialties, and tour guides. The number of visitors could be more than 1,000 people per month, and village income was able to reach IDR 200 million per month in 2018 .

The attractiveness of the Special Region of Yogyakarta as a tourist destination is still high because of its innovative, creative and empathetic community support, such as the holding of the Biennale Jogja, which is regularly organized every year and is participated by participants from various countries and regions outside Yogyakarta. The Biennale Jogja XV was participated by 33 artists from the country and 19 artists from ASEAN which lasted 40 days. Similarly, the Prambanan Jazz Festival event at the Prambanan Temple Complex has been going on for five years, participated by Indonesian and foreign musicians, such as Diana Krall, Sarah Brightman, and an Irish vocal group, Boyzone. This kind of event has multi-effects in various fields, including economic equality, increasing local revenue, and international branding.

In addition to Prambanan Temple, Borobudur Temple which is located 7 kilometers from Magelang also has already had a fixed agenda, such as the Borobudur Marathon which is held every year. Besides, there are also a Village Economic Center, bicycle facilities for rent with all amenities, Manohara Hotel and others which are expected to reach around 2 million people by 2019. However, the target seems difficult to achieve, especially foreign tourists, due to the absence of a hospital, no routine schedule for performing arts, and inadequate infrastructure and supporting facilities, for example the development of tourist line from Yogyakarta International Airport to Borobudur via Menoreh Hills, while the people in the Borobudur area seem enthusiastic to attract tourists by providing cheap lodging, catering, motorbike and bicycle rental by promoting hospitality.

Borobudur Temple is increasingly in demand by travelers after the presence of De Loamo Glamping, a nomadic concept resort in Sedayu Village, Purworejo covering an area of one hectare 
which is part of the Borobudur Highland area, and is managed by the Borobudur Authority Agency. With a location of about 12 kilometers from the Borobudur Temple, it is expected to increase competitiveness and boost and prolong the visit. De Loamo Glamping is also harmonized with the potential of tea garden tourism in Pagerharjo Village, Samigaluh District, Kulon Progo Regency. In addition, off-road tours are also available by jeep to explore the pine forest and Menoreh Hills.

Tourism is very reliable because it has a very fast effect and has multiple impacts on the eyes of tourists. They not only see beautiful scenery, but also stay overnight, taste food and drinks, shop, and enjoy the activities provided by the locals. But the prestige of Bali until now still occupies the highest position and become the first tourist destination in Indonesia. This means that the attractiveness of tourist destinations other than Bali must be increased so that tourists do not hesitate to visit these destinations and can make long trips and spend their money in Indonesia.

Incessant efforts by the government to offer 10 tourist destinations as a priority for tourism development must be accompanied by careful measures to avoid over tourism as a result of tourism exploitation that can erode the carrying capacity of the environment, ecology, social and culture. One worrying example is that groundwater conditions in Bali are increasingly critical due to being sucked in by the tourism business, as well as the scandal of smuggling 41 Komodo dragons from Komodo Island to abroad. Other factors that also need improvement are unfair price competition between conventional travel agents, including illegal practices that only promote via social media or the internet to attract potential tourists. The purity of the environment, ecology and local culture must be protected because it is a long-term investment and can increase Indonesia's bargaining power in the eyes of the world.

Another thing that is also very important with regard to tourism is that Indonesia has a sailing tourism line of 3,000 nautical miles which does not get typhoons throughout the year. This shows that Indonesian sailing tourism can take place in a full year with different locations. However, the development of sailing tourism in Indonesia does not only require the construction of physical infrastructure in the form of tourism ports, but also include local human resource management, control by the local government, and marketing strategies to foreign markets, including ensuring the safety and comfort of travelers.

Indonesia already has several sailing boat festival agendas, including Sail Indonesia, Wonderful Sail to Indonesia, and the Darwin-Ambon Yacht Race. However, the interaction and economic benefits received by local residents have not been optimal so it is necessary to realize inclusive tourism to improve the living standards of the local community by always paying attention to local wisdom.

Basically tourism market is formed because of the balance of demand and supply. There are many factors that affect the amount of demand and supply in the tourism market. Tourism demand is influenced by the amount of revenue, the effect of promotion, the price of airplane or ship tickets, the availability of infrastructure and facilities, the agenda of tourism security activities, and others. Meanwhile tourism supply is more influenced by the excellence and uniqueness of tourist destinations, hotels or lodging facilities, games, entertainment, souvenirs, and others.
Table 4: Destination Attractiveness

\begin{tabular}{|c|c|}
\hline Core Resources \& Attractors & $\begin{array}{l}\text { Supporting Factors \& } \\
\text { Resources }\end{array}$ \\
\hline Mix of Activities & Facilitating Resources \\
\hline $\begin{array}{l}\text { Sports tourism, } \\
\text { fashion, music, cultural } \\
\text { performances, souvenirs } \\
\text { and culinary, which are } \\
\text { associated with natural } \\
\text { beauty and history. } \\
\text { Holding international } \\
\text { events, such as } \\
\text { sports tourism, ballet } \\
\text { performances, painting } \\
\text { exhibitions, and music } \\
\text { performances. } \\
\text { Tour packages are less } \\
\text { integrated and packaging } \\
\text { tends to be monotonous. }\end{array}$ & $\begin{array}{l}\text { Tourism facilities } \\
\text { tend not to change } \\
\text { and there are no new } \\
\text { sensations to attract } \\
\text { tourists. } \\
\text { Tourists are always } \\
\text { looking for new, } \\
\text { unique, pleasant, and } \\
\text { relaxing places that } \\
\text { are integrated in one } \\
\text { area, or close to one } \\
\text { another. } \\
\text { Tourism not only } \\
\text { requires branding, } \\
\text { but also intensive } \\
\text { promotion. }\end{array}$ \\
\hline Destination Management & Qualifying Determinants \\
\hline Organization & Location \\
\hline $\begin{array}{l}\text { - Ministry of Tourism } \\
\text { and Creative Economy } \\
\text { / Tourism and Creative } \\
\text { Economy Agency of the } \\
\text { Republic of Indonesia. } \\
\text { Provincial, Regency and } \\
\text { City Government Tourism } \\
\text { Offices. } \\
\text { Center for Conservation of } \\
\text { Culture. } \\
\text { Ministry of Transportation, } \\
\text { Ministry of Transportation, } \\
\text { Transportation Agency of } \\
\text { Provincial, Regency and } \\
\text { City Governments. } \\
\text { Ministry of Public Works } \\
\text { and Public Housing (PUPR), } \\
\text { Provincial, Regency, and } \\
\text { City Government. }\end{array}$ & $\begin{array}{l}\text { The government, } \\
\text { after establishing } \\
10 \text { strategic national } \\
\text { tourism areas. } \\
\text { Tourist destinations } \\
\text { are scattered in } \\
\text { various regencies } \\
\text { / cities that require } \\
\text { ease of accessibility } \\
\text { and completeness of } \\
\text { facilities on site. } \\
\text { Tourist villages } \\
\text { emerge and are } \\
\text { managed according } \\
\text { to local wisdom. } \\
\text { Mall, hotel, } \\
\text { restaurant, } \\
\text { merchandise shop. }\end{array}$ \\
\hline
\end{tabular}

Source: Researcher, 2019, Adopted from OECD, 2009

Based on information in Table 5, domestic tourists expect that during the tour they feel comfortable, safe, friendly, and always look at social media to determine one or more tourist destinations. Domestic tourists prefer tourist destinations that provide playground, especially when bringing children, while foreign tourists prefer destinations that have good prestige and privacy, in the sense that they are not chased by traders, beggars, and those who suddenly ask to take pictures, or serve as a spectacle.

For domestic and foreign tourists, the unique tourism experience is a target, and price is not a major problem because the most important thing is to get interesting experiences and stories that are worth paying, including experiences that cannot be done in the country of origin of foreign tourists.

The tourism market is experiencing rapid development due to lifestyle changes, the emergence of new tourist attractions, the incessant promotion of tourism, and the rapid development of 
attractive and affordable creative products. This is in line with the viewpoint of Crouch \& Ritchie (1999) that there are many factors that influence the demand and supply in tourism, including factors that are ignored by many stakeholders, such as toilet cleanliness, the expensive price of flight ticket to get to main destination, discrimination on the price of ticket to enter tourist attraction sites between domestic and foreign tourists, including the price of souvenirs. Indifference, or without any effort to improve and change, makes Indonesia's tourism competitiveness be inferior to other countries, such as Singapore and China, that regularly make innovations and develop creativity,.

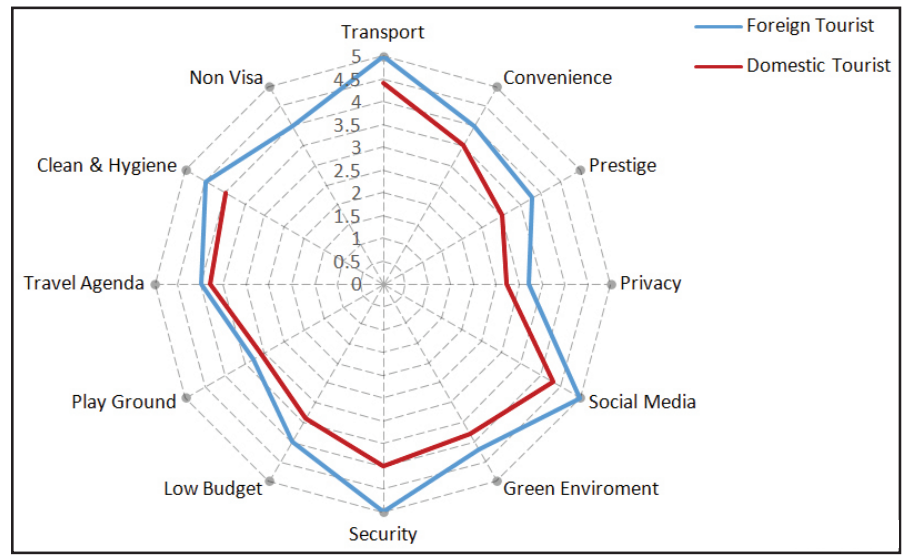

Fig. 1:

Source: Tourism of Attribute, Researcher, 2020.

The demand for tourism is a major determinant of profitability for tourism business actors. Tourism demand is always a function of several variables, namely price, income, security, travel agenda, hospitality, convenience, playground, and promotion. The next step after collecting primary data derived from the results of interviews and observations is tidying the diary, coding, and tabulating. Assuming that tourism (Y) is a function of several variables (X), the next stage is to determine the form of the dependence of the variable $\mathrm{Y}$ on the variable $\mathrm{X}$ which is expressed in linear form as a condition of regression analysis:

$\operatorname{Tourism}(Y)=a+b_{1} x_{1}+b_{2} x_{2}+\ldots+b_{n} x_{n}+e$

Regression analysis is used to find the degree of dependence of one variable on more than one variable to find the value of the coefficients of the demand function, given that the coefficients indicate the influence of the variables that determine the demand for tourism products, such as natural tourism, artificial tourism, historical tourism, religious tourism, business tourism, shopping tourism, and museum tourism.

\section{Concluding Remarks}

It is time for tourism and creative industries to become the backbone of the national economy in order to overcome the current account deficit and the state budget deficit. The huge potential of tourism and the creative economy can have a big leap effect on the development of the nation's economy, especially since tourism actually grows from the bottom. Thus, collaboration between the Central and Regional Governments is needed so that the tourism sector is able to make a positive contribution to regional development, employment, retribution, foreign exchange, and others while always preserving the nature and local culture. Local wisdom should still be maintained and even introduced to travelers so that they will always maintain the sustainability of local tourist destinations, including implementing sustainable tourism.

The development of tourism in Indonesia is not only in infrastructure, but also in ecosystems in an effort to support the success of tourist destinations, such as aspects of culture, creativity, and hospitality so that people around the tourist destinations are not just spectators. Thus the development of tourism is expected to provide economic benefits, maintain the environment, and empower people in the real sense.

\section{Acknowledgements}

The research was funded by University of Surabaya.

\section{References}

[1] Arsyad, Lincolin 2008, Ekonomi Manajerial, Ekonomi Mikro Terapan Untuk Manajemen Bisnis, BPFE, Yogyakarta.

[2] Chariri, Anis. 2009. Landasan Filsafat dan Metode Penelitian Kualitatif. Makalah, Workshop Metodologi Penelitian Kuantitatif dan Kualitatif. Fakultas Ekonomi Universitas Diponegoro. Semarang.

[3] Chreswell, John W., 2010, Research Design, Pendekatan Kualitatif, Kuantitatif dan Mixed, Pustaka Pelajar, Yogyakarta.

[4] Crouch, Geoffrey I.; Ritchie, J.R. 1999. The Impact of Culture on Tourism: OECD.

[5] Firdaus, Haris. Regina Rukmorini, 2019.Daya Kreatif Tiada Akhir, Kompas, 17 November 2019, Jakarta.

[6] Florida, Richard. 2001. The Rise of the Creative Class. New York : Oxford University Press.

[7] Gelgel, I Putu. 2009. Industri Pariwisata Indonesia dalam Globalisasi Perdagangan, Jasa, Implikasi Hukum dan Antisipasinya. PT Refika Aditama : Bandung.

[8] Hadiwijoyo, Suryo Sakti. 2012. Perencanaan Pariwisata Pedesaan Berbasis Masyarakat. Graha Ilmu : Yogyakarta.

[9] Howkins, John. 2001. The Creative Economy, How People Make Money From Ideas. Penguin Books.

[10] Asia Pacific Creative Communitie : A Strategy for the 21st Century Senior Expert Symposium. Jodpur. India. 22-26 February 2005.

[11] Keesing, Roger M. 1974. Annual Review of Anthropology. Institute of Advence Studies : Australia.

[12] Moleong, Lexy J. 2004. Metode Penelitian Kualitatif. PT. Remaja Rosdakarya : Bandung.

[13] Moelyono, Mauled. 2010. Menggerakkan Ekonomi Kreatif :Antara Tuntutan dan Kebutuhan. Rajawali Pers. Raja Grafindo Persada. Jakarta.

[14] Outra, Wyasa. 2003. Hukum Bisnis Pariwisata. PT Refika Aditama : Bandung.

[15] Pendit, Nyoman S. 2006. Ilmu Pariwisata Sebuah Pengantar Perdana. Pradnya Paramita : Jakarta.

[16] Schmool, G.A. 1977. Tourism Promotion. Tourism International Press : London.

[17] Spillane, James. 1989. Pariwisata Indonesia :Sejarah dan Prosesnya. Kanisius : Yogyakarta.

[18] Suryana. 2000. Ekonomi Pembangunan :Problematika dan Pendekatan. Salemba Empat: Jakarta.

[19] Suwantoro, Gamal. 2004. Dasar Dasar Pariwisata. Andi : Yogyakarta.

[20] Utama, I Gusti Bagus Rai. 2016. Pengantar Industri Pariwisata. Dee publish : Yogyakarta.

[21] Wahab, Salah, 2003. Manajemen Kepariwisataan. Pradnya Paramita : Jakarta. 
[22] Yoeti, Oka A. 2008. Ekonomi Pariwisata :Introduksi, informasi dan implementasi. PT Kompas Media Nusantara : Jakarta.

[23] Tayibnapis, Ahmad Zafrullah. Lucia Endang Wuryaningsih. Radita Gora. 2018. The Development of Digital Economy in Indonesia, International Journal of Management \& Business Studies, Vol.08, Issue 3, Version July-Sept, 2018. India

[24] Development of Tourism and Creative Economy in Indonesia, International Annual Symposium on Management, Proceeding, Tanjung Pinang, Riau Island, March 4rd-6rd, 2018. Indonesia.

[25] Companies in Indonesia in the Fortex of Global Economic Disruption, International Annual Symposium on Management, Proceeding, Manado, March 4-6, 2019. Indonesia.

[26] Pentingnya Inovasi dan Kreativitas Era Teknologi Digital. Seminar Nasional dan Call for Papers. Senima 4. Universitas Negeri Surabaya. Proceeding. 5 October 2019. Surabaya. Indonesia.

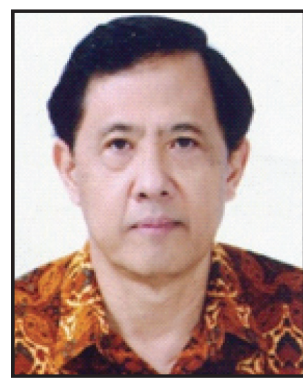

Ahmad Zafrullah Tayibnapis graduated from Economic Faculty of Surabaya University, Surabaya, Indonesia at 1980. Master Graduate from Gadjah Mada University, Yogyakarta, Indonesia at 1991. He has been Associate Professor of Economic and Business Faculty of Surabaya University at 1979-2021. His research interest included industrial economic, Indonesia's Tourism, Indonesia Economics, and International Economics.

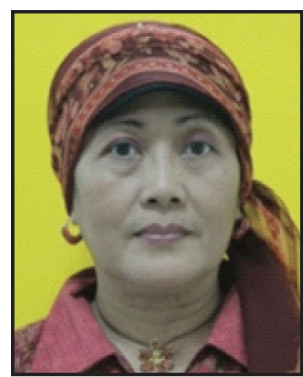

Made Siti Sundari graduated From Economic Faculty of Airlangga University, Surabaya, Indonesia. Master Graduate from Brawijaya University, Malang, Indonesia. Ph.D graduate from Brawijaya University, 2015. She was lecturer in Surabaya University. Her research interest included industrial economic, Indonesia Economics, and International Economics. 